REVIEW ARTICLE

\title{
Autophagy provides a conceptual therapeutic framework for bone metastasis from prostate cancer
}

\author{
YouZhi Wang ${ }^{1,4}$, Ning $\mathrm{Wu}^{2,3,4}$ and Ning Jiang (iD) \\ (c) The Author(s) 2021, corrected publication 2021
}

Prostate cancer is a common malignant tumor, which can spread to multiple organs in the body. Metastatic disease is the dominant reason of death for patients with prostate cancer. Prostate cancer usually transfers to bone. Bone metastases are related to pathologic fracture, pain, and reduced survival. There are many known targets for prostate cancer treatment, including androgen receptor (AR) axis, but drug resistance and metastasis eventually develop in advanced disease, suggesting the necessity to better understand the resistance mechanisms and consider multi-target medical treatment. Because of the limitations of approved treatments, further research into other potential targets is necessary. Metastasis is an important marker of cancer development, involving numerous factors, such as AKT, EMT, ECM, tumor angiogenesis, the development of inflammatory tumor microenvironment, and defect in programmed cell death. In tumor metastasis, programmed cell death (autophagy, apoptosis, and necroptosis) plays a key role. Malignant cancer cells have to overcome the different forms of cell death to transfer. The article sums up the recent studies on the mechanism of bone metastasis involving key regulatory factors such as macrophages and AKT and further discusses as to how regulating autophagy is crucial in relieving prostate cancer bone metastasis.

Cell Death and Disease (2021)12:909; https://doi.org/10.1038/s41419-021-04181-x

\section{FACTS}

- The most usual metastatic location in prostate cancer is bone metastasis.

- Metastatic prostate cancer has a high death rate in advanced prostate cancer patients, but there is no good treatment model so far.

- There are many studies on the association between autophagy and cancer metastasis; however, it is rarely correlated to bone metastases models of prostate cancer.

\section{OPEN QUESTIONS}

- Can we inhibit autophagy activity of cancer cells to inhibit bone metastases from prostate cancer by linking classical signal transduction pathways?

- Can this autophagy model of bone metastasis be established successfully? Does it inhibit tumor metastasis in the primary site or inhibit tumor growth that has already been metastatic?

- To what extent would deeper understanding of autophagy and bone metastasis help improve human survival?

\begin{abstract}
INTRODUCTION
Prostate cancer (PC) is the second most common malignancy in males [1]. With improvement in diagnosis and treatment, reports of cases with PC have been increasing every year in China [2]. The prostate is made up of two layers of epithelial cells: basal epithelial cells and luminal epithelial cells [3]. Interestingly, these two cell types express profile of androgen receptors (ARs) differently. Nearly all luminal epithelial cells express AR and AR signal is necessary for them to survive; however, basal epithelial cells are usually ARnegative and hence insensitive to castration. Charles Huggins reported that PC relies on AR signal, similar to luminal epithelial cells, based on which human PC has been widely deemed to be derived from luminal epithelial cells. Like many other types of cancer, PC cells exhibit heterogeneity generally [4-6]. Metastatic PC accounts for only $5-6 \%$ of new cases of PC in the European and American populations, while in China, the rate is as high as $54 \%$ $[7,8]$. Of note, among all PC metastases, bone metastases are predominant [9].

Autophagy is a gene-regulated process in eukaryotes. It regulates organelles and protein degradation so that they can be recycled $[10,11]$. In normal cells, autophagy can inhibit the occurrence of tumors and prevent them from becoming cancerous. Contrarily, autophagy drives the migration and proliferation of tumor cells [12, 13]. Merging lysosomes with autophagosomes can enhance the sensitivity of tumor cells to
\end{abstract}

\footnotetext{
'Department of Urology, Tianjin Institute of Urology, The Second Hospital of Tianjin Medical University, 300211 Tianjin, China. ${ }^{2}$ The First Department of Breast Cancer, Tianjin Medical University Cancer Institute and Hospital, National Clinical Research Center for Cancer, Key Laboratory of Cancer Prevention and Therapy, 300060 Tianjin, China. ${ }^{3}$ Tianjin's Clinical Research Center for Cancer, Key Laboratory of Breast Cancer Prevention and Therapy, Tianjin Medical University, Ministry of Education, 300060 Tianjin, China. ${ }^{4}$ These authors contributed equally: YouZhi Wang, Ning Wu. ${ }^{\circledR}$ email: jiangning@tmu.edu.cn

Edited by: Professor Gian Maria Fimia
}

Received: 10 June 2021 Revised: 1 September 2021 Accepted: 16 September 2021

Published online: 05 October 2021 
various treatments, including DNA damage agents, anti-hormone therapy, and radiotherapy. Autophagy acts mainly by regulating the phosphoinositide-3 kinase (PI3K)/AKT pathway $[14,15]$.

At present, the studies of bone metastasis from PC are not extensive enough, and most of the studies have not been combined with autophagy. However, autophagy plays an indispensable role in tumor metastasis. So it is important to provide a model of bone metastasis and a conceptual treatment model for PC. This paper introduces the relationship between tumor and autophagy and reviews all the studies affecting bone metastases from PC in the past decade, as well as the relationship between these mechanisms and autophagy. Moreover, we discussed whether autophagy is important in the process of bone metastasis from $\mathrm{PC}$, and how to control it to inhibit tumor growth.

\section{METASTASIS OF PC}

The major reason of PC patients' death is metastatic disease [16]. The first site of metastasis are usually the lymph nodes that are near the main tumors, followed by liver, lung, and bone [17]. Bone metastases from PC most commonly present as osteoblastopathy with osteolytic function that can cause frequent fractures, hypercalcemia, and sharp pain [18, 19]. Epithelial-mesenchymal transition (EMT) plays a key role in the metastases of different types of cancers, such as PC. Although its role in body is controversial, it has been extensively reviewed elsewhere. PCs pass through EMT, spread to circulating tumor cells, conquer obstacles of body and establish bone metastasis, cross the sinus wall and bone marrow stroma, and move to the endosteum appearance through the sinus vessels in the bone marrow cavity [20-22].

When PC cells localize the bone marrow, the mutual effect between the cancer cells and the microenvironment of bone leads to a bad circle of the destruction and regeneration of bone, a process which supports the survival of cancer cells and the growth of tumors [23-25]. PC cells secrete growth factors, including adrenomedullin, endothelin 1, bone morphogenetic proteins, fibroblast growth factors, and platelet-derived growth factor (PDGF), which can stimulate osteoblasts to activate and form new bone by paracrine signals [26]. In addition, protease secreted by tumor (urokinase-type plasminogen activator, prostate-specific antigen (PSA), and matrix metalloproteinases) promotes the release of osteoblast-induced growth factors, such as insulin-like growth factors, PDGF, and transforming growth factor $\beta$ (TGF- $\beta$ ), which further enhances the differentiation of mesenchymal stem cells into osteoblasts [27]. Activated osteoblasts result in increased receptor activator of nuclear factor kappa-B ligand (RANKL) concentration, hypocalcemia, and parathyroid hormone release that respond to hypocalcemia. Both activate osteoclasts and subsequently release factors such as TGF- $\beta$ through osteoclast-mediated bone resorption [28]. The factors increase the survival ability of PC cells, produce proteins including parathyroid hormone associated proteins, and promote the production of RANKL and osteoprotectin downregulation in osteoblasts and stromal cells. This results in further osteoclast activation. Wnt signal transduction pathways activated in PC cells is also important in driving osteogenic differentiation. Prostate transmembrane protein androgen-induced 1 is a TGF- $\beta 1$-induced gene that inhibits bone metastases of PC by blocking TGF- $\beta$ signal transduction by interacting with HECT E3 ubiquitin ligase and Smad2/3 [29]. Monoamine oxidase $A$, a mitochondrial membrane-conjugated enzyme that can catalyze degradation in biology and diet, has shown its crucial role in the EMT process through oxidative deamination, promoting bone metastasis and inducing RANKL expression and interleukin-6 (IL-6) by activating paracrine Shh signal transduction in osteoblasts [30, 31]. To sum up, the continuous growth of metastatic PC cells involves a dynamic bone remodeling process that results from the interaction of cancer cells, osteoblasts, and osteoclasts (Fig. 1).

DIFFERENT FACTORS AFFECTING BONE METASTASIS FROM PC

To date, many studies have been published on pathways that influence bone metastasis from PC. Many articles have made indepth discussions on bone metastasis, some of which are based on animal model verification, some of which focus on case collection and in-depth immunohistochemistry, and more articles focus on more detailed studies on the cellular mechanism. In order to better ensure the accuracy and timeliness of the mechanism, we selected all the articles (2000-2021) that affect bone metastasis from PC. All the mechanisms affecting bone metastasis from PC can be separated into the following types: (1) $\mathrm{PI} 3 \mathrm{~K} /$ Akt signal transduction pathway is dominant [32-36]; (2) TGF- $\beta$ signal transduction pathway was dominant [37-39]; (3) miRRNA was dominant [34, 35, 40-42]; (4) other signal transduction pathways and drugs [36, 39, 43-64] (Fig. 2).

\section{AUTOPHAGY AND PI3K/AKT/MAMMALIAN TARGET OF RAPAMYCIN (MTOR)}

Autophagy is a very conservative cellular metabolic process that can be activated under different cellular pressure environments [65]. Eukaryotic cells transport unnecessary and possibly harmful cytoplasmic materials to lysosomes for digestion [66]. At this point, the major pathways of autophagy substrate transfer to lysosomes are macrophages, chaperon-mediated autophagy, and microautophagy [67].

Autophagy responds to a variety of cytotoxic injuries, thereby enhancing survival and preventing damage to cells lacking energy or nutrients. Therefore, adapting to the changing circumstances, autophagy needs rigorous regulation so that it can respond to different stimuli accurately $[68,69]$. Autophagy is maladjusted in many conditions, even in tumors. Autophagy regulation is expected to be a cancer therapy strategy $[70,71]$. BECN1 is a center protein forming the BECN1-VPS34-VPS15 complex by aggregating cofactors, which triggers the cascade of autophagy protein [72]. AMBRA1 is important in autophagy regulation. Some studies have demonstrated that VPS34, BECN1, and AMBRA1 are parts of autophagy promoter complex. Besides, AMBRA1 downregulation shortens the ability of BECN1 and the activity of kinase VPS34 to connect with its VPS34 connection [73].

The autophagy main mechanism is composed of about 40 proteins in yeast. And autophagy is mainly caused by unc-51 like autophagy activating kinase 1 (ULK1) complex [10, 74]. ULK1 complex in human is composed of the FIP200 (FAK family kinase interacting protein of $200 \mathrm{kDa}$; also called RB1CC1) scaffold, the ULK1 protein kinase and the Hop/Rev7/Mad2 domain, including ATG101 protein and ATG13 protein [74]. Moreover, ULK1 is regulated by energy status and amino acid by mTORC1 (mechanistic target of rapamycin-1) and AMPK (AMP activated protein kinase) kinases. When mTORC1 is activated, ATG13 and ULK1 phosphorylation inhibit autophagy, thereby reducing ULK1 kinase activity [11]. Besides, the Ras-like $\mathrm{G}$ protein RalB can trigger the catalytic activity of BECN1-VPS34 and ULK1 complexes to promote biogenesis of autophagosome by directly binding to Exo84 $[75,76]$. Another research discovered that ULK1 activation on mTOR inhibited S14 and promoted the activity of the VPS34 complex containing ATG14L [77].

Cancer cell autophagy involves many pathways. For example, the signal transduction pathway of JUK/cJun, AMPK/mTOR/ p70S6K, Hh, ERK/AKT/mTOR/STAT3/Notch, Wnt/beta-catenin, Notch1/Hes-1, epidermal growth factor receptor (EGFR)/Ras/ MEK/ERK, P38MAPK, and EGFR/Ras/MEK/ERK [77-79]. In particular, the $\mathrm{PI} 3 \mathrm{~K} / \mathrm{AKT} / \mathrm{mTOR}$ pathway as a regulatory pathway for autophagy has attracted extensive attention $[14,80]$. The mTOR 


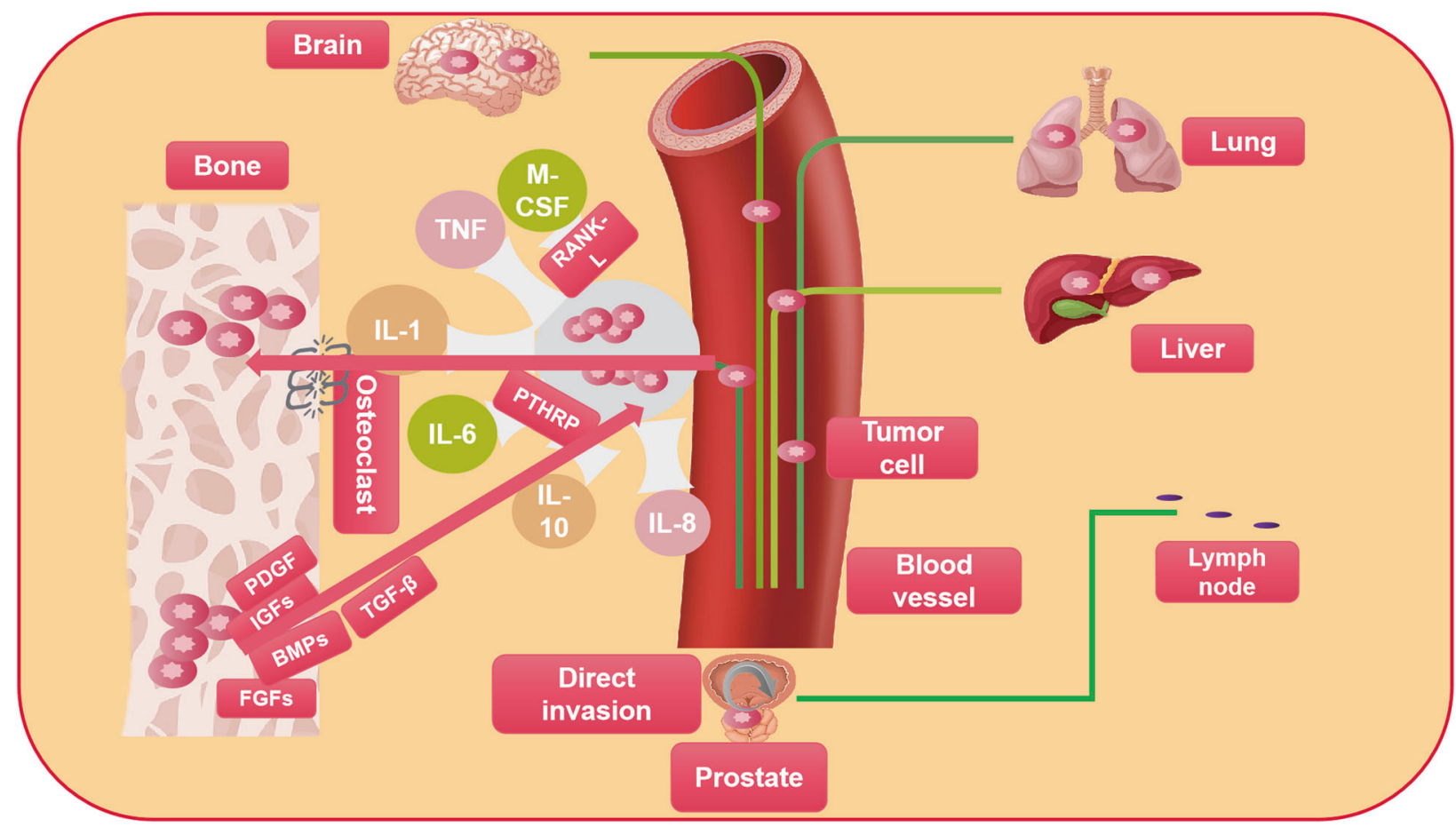

Fig. 1 The basic metastatic sites and pathways of PC and the vicious circle of osteolytic metastasis. Prostate cancer mainly metastases to the bone, but some tumor cells also spread through the blood to the viscera, such as the lung, liver, and brain. In addition, PC can also develop direct spread and lymph node metastasis. Parathyroid hormone-related peptides secreted by tumor cells are the major stimulators of osteoclast formation. Additionally, cancer cells also generate other factors, the formation of which promote osteoclasts, including prostaglandin E2 (PGE2), interleukin, macrophage colony-stimulating factor (M-CSF), and tumor necrosis factor. These factors increase the expression of nuclear factor-KB ligand receptor activators (RANKL), which acts on preosteoclast to induce bone resorption and osteoclast formation directly. Bone resorption releases factors including platelet-derived growth factor (PDGF), fibroblast growth factors (FGFs), insulinlike growth factors (IGFs), bone morphogenetic proteins (BMPs), and transforming growth factor b (TGF-b), which can enhance the parathyroid hormone-related peptide production through cancer and growth factors, thereby promoting tumor growth. Tumor growth and bone destruction are further increased because of the symbiotic connection between tumor growth and bone destruction.

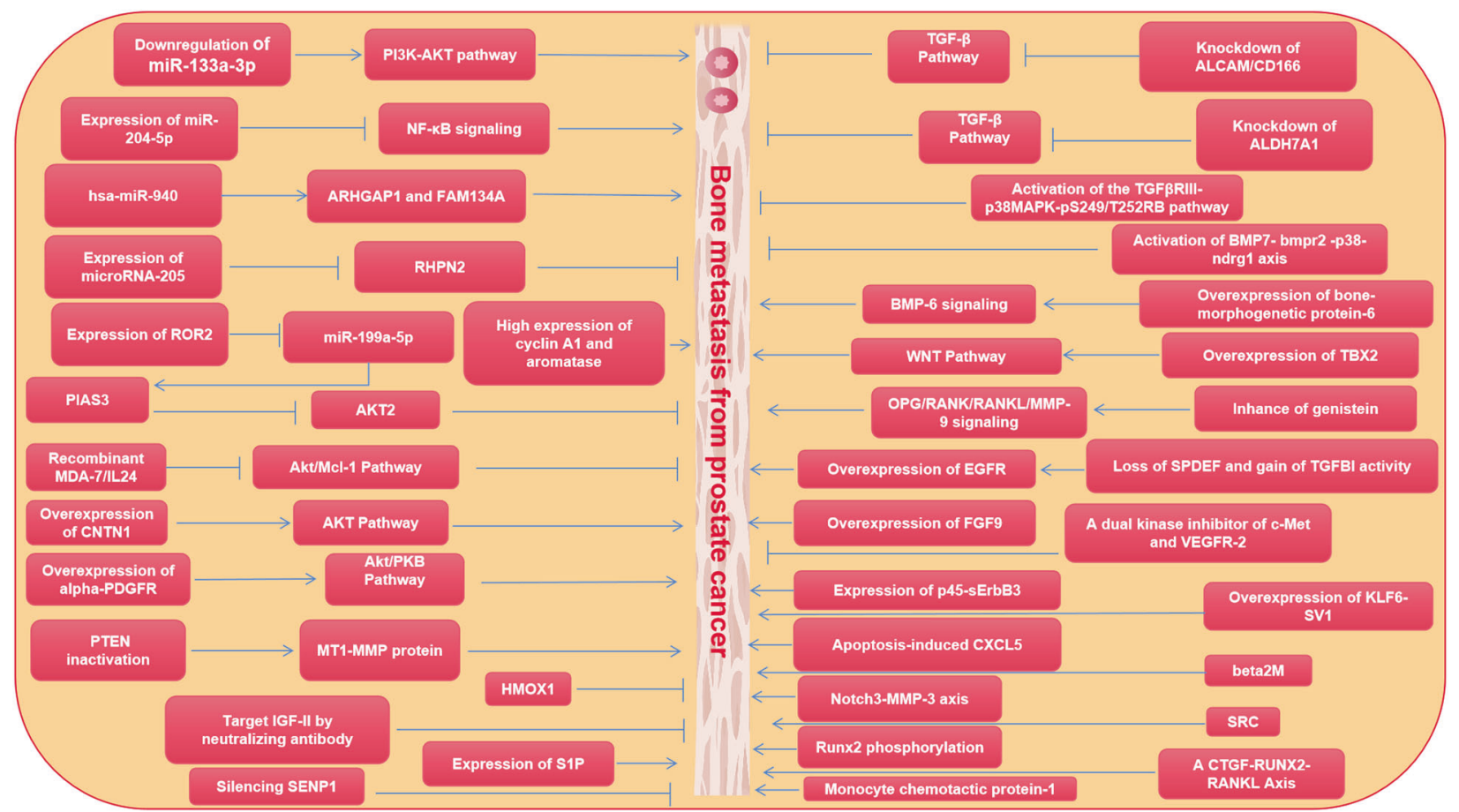

Fig. 2 Different factors that inhibit or promote bone metastasis from PC. Influence of different signaling pathways and drugs on bone metastasis from PC. 
Table 1. Compounds and genes known to regulate autophagy and that are associated with the PI3K/AKT/mTOR signaling pathway.

\begin{tabular}{|c|c|c|}
\hline $\begin{array}{l}\text { Compounds and genetic } \\
\text { methods }\end{array}$ & Effect & Reference \\
\hline $10-\mathrm{NCP}$ & $\begin{array}{l}\text { 10-(40- } N \text {-diethylamino)butyl)-2-chlorophenoxazine; an AKT inhibitor that induces autophagy in } \\
\text { neurons }\end{array}$ & [96] \\
\hline ESC8 & $\begin{array}{l}\text { A cationic estradiol derivative that induces autophagy and apoptosis simultaneously by } \\
\text { downregulating the MTOR kinase pathway in breast cancer cells }\end{array}$ & [98] \\
\hline Everolimus & $\begin{array}{l}\text { An inhibitor of MTORC1 that induces both autophagy and apoptosis in B cell lymphoma primary } \\
\text { cultures }\end{array}$ & [99] \\
\hline KU-0063794 & An MTOR inhibitor that binds the catalytic site and activates autophagy & {$[100,101]$} \\
\hline NVP-BEZ235 & A dual inhibitor of PIK3CA/p110 and the MTOR catalytic site that activates autophagy & [102-104] \\
\hline
\end{tabular}

Supplementary: this table is not meant to be complete, as there are many compounds and genetic methods that regulate autophagy, and new ones are being discovered routinely.

is the central inspection point for autophagy negative regulation and antitumor agents through inhibiting the PI3K/AKT/mTOR pathway to stimulate autophagy [81]. At present, autophagyrelated inhibitors or promoters have been successively discovered and proved. To better verify the related role of Akt and autophagy, different compounds and gene methods were screened to affect the PI3K/AKT/mTOR signal transduction pathway by regulating autophagy (Table 1 ).

\section{AUTOPHAGY AND BONE METASTASIS: FOE OR FRIEND?}

The progress of autophagy, Akt pathway, and tumor bone metastasis in other tumors is also limited, and the research is mainly focused on osteosarcoma [82, 83]. Further results show that autophagy is involved in the in vivo and in vitro model of osteosarcoma development and metastases [83]. Spreading metastatic cells must face a number of adverse factors, such as separation from extracellular matrix, immune cell attack, and an environment devoid of oxygen or growth factors. These conditions lead to increased production of cellular ROS, insufficient energy status, and DNA damage [84, 85]. Apoptosis is stimulated by low level of death signals, while high levels often cause necroptosis. Because of the function of the necroptosis and apoptosis mechanisms, cells with metastasis capability from major tumors cannot metastasize in a large size successfully $[71,86]$. Autophagy is quite variable compared to apoptosis and necrosis. On the one hand, autophagy improves the large adaptation of metastatic cells under stress and further to combat necrosis and apoptosis. In addition, autophagy can reduce metastasis by inhibiting blocking inflammatory immune cell infiltration and tumor necrosis $[71,87]$. Interestingly, excessive autophagy induces metastasis cell death [88, 89]. Autophagy is currently being investigated as both a modulator and target in PC. While it can have very subtle effects on cells, it is quite different from the internal environment of the cell; specifically, autophagy interacts with cancer cells (Fig. 3). Autophagy inhibits the carcinogenesis of normal cells and promotes the growth of tumor cells [71]. Moreover, cell growth or death simultaneously affects the autophagic activity in the tumor environment $[90,91]$. Therefore, to learn the relationship between metastatic tumor and autophagy, it is necessary to learn the relationship between PC cells and autophagy.

Most animal models of preclinical PC metastasis have been made by directly injecting well-defined cell lines into recipients with immune deficiency. Immunodeficient animals with immune deficiency are often necessary for cell line injection model, especially where the cell type of origin is different from the host [44]. The animal model is difficult to achieve success, as the cell line, mouse strain, and injection site quantified as tumor extraction rates need to be assured (Table 2). Various cell lines have been established (ATCC sold 14 prostate tissue cell lines). The width of useful cell lines is noteworthy because every cell line has their own genetic spectrum that can be applied for modeling various aspects of PC, such as reactivity of hormone, antigenicity, and ability of metastasis. Established PC cell lines are most commonly derived from DU145, PC3, or LNCaP cells, though other cell lines exist. Primary cell lines are usually defined based on some biochemical features, such as PSA expression or AR dependency, and can be selected as needed for experimental or therapeutic evaluation (Table 3). Similarly, a wide variety of transfer cell lines can be used in animal models to study metastasis.

After autophagy stimulation, LC3 puncta, a typical autophagy marker, were not detected in DU145 cells, indicating a lack of autophagy function in this cell line [92]. And published researches have revealed that the autophagic activity of $\mathrm{PC}$ / LNCaP cells is higher than that of other PC cells [92]. Therefore, it is appropriate to select these two cell lines to construct the model. By adding autophagy inhibitors that are associated with AKT pathway, we can inhibit cells' autophagy activity further, and the size and invasiveness of bone metastatic tumor could be significantly reduced.

\section{CONCLUSION AND FUTURE DIRECTION}

In this article, we primarily considered whether metastatic bone tumors from PC could be inhibited or induced by altering the autophagic activity of PC cells. First, by summarizing the published studies on the pathways affecting bone metastasis from PC, we found that the AKT signaling pathway is important in bone metastasis from PC. Then the relationship across AKT, EMT, autophagy, and metastatic tumor was gradually elucidated through careful logical scrutiny, so as to judge the feasibility of this treatment scheme. Finally, we concluded that there is a strong correlation between AKT-related signaling pathway and autophagy, and it can affect the formation of bone metastasis of PC by influencing the internal connection between them. Moreover, the influence of autophagy on the occurrence and development of bone metastasis was explored. Inhibiting the autophagic activity 


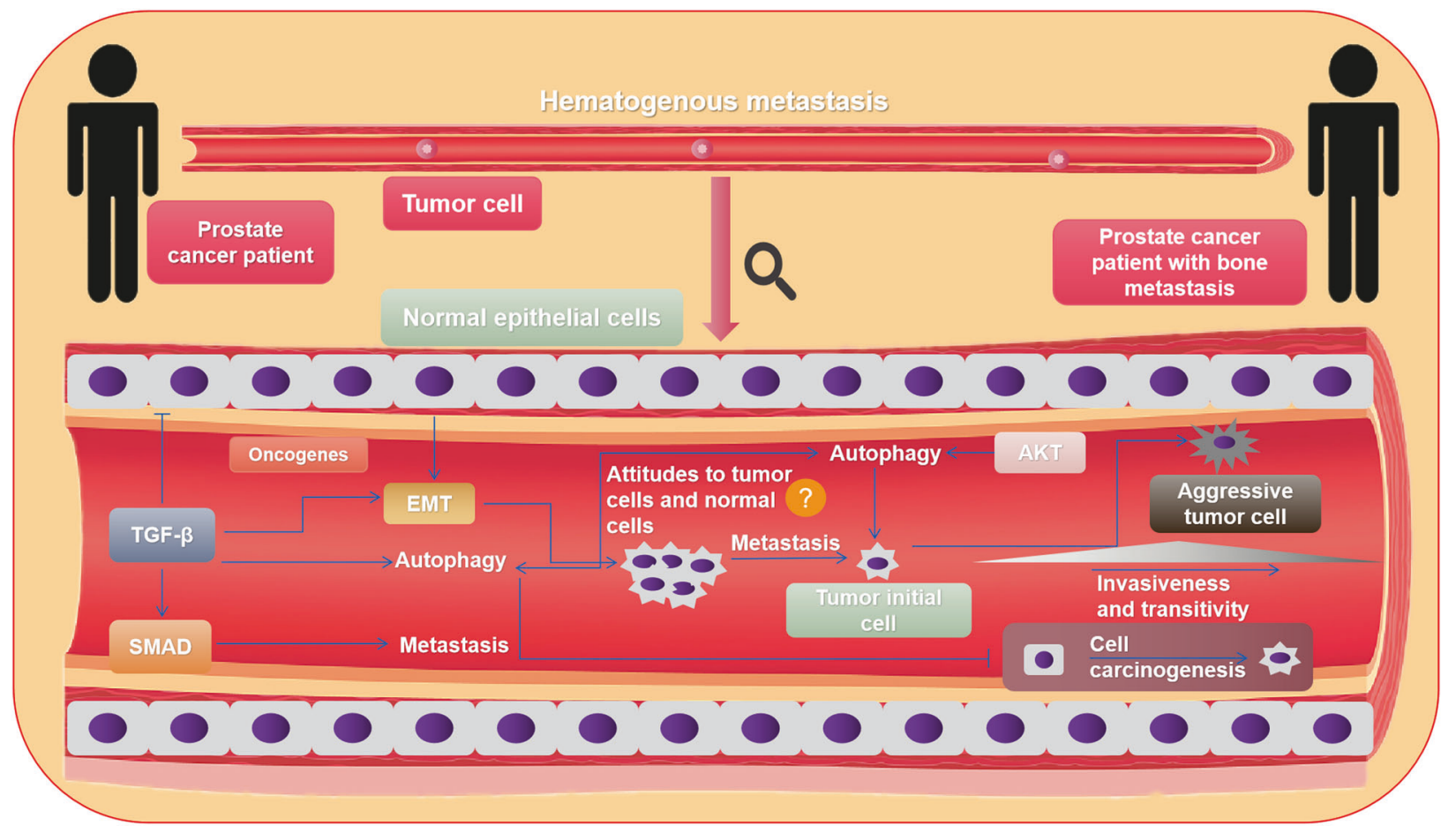

Fig. 3 The mechanism of metastasis via blood in advanced bone metastasis from PC. Bone metastasis from PC mainly occurs via blood, where multiple signaling pathways are involved. Focus on the AKT signaling pathway, which has a remarkable relationship with autophagy, and TGF- $\beta$ signaling pathway, which can induce EMT formation and release Smad protein to promote tumor metastasis.

Table 2. Commonly used cell lines in the translational models of prostate cancer.

\begin{tabular}{|c|c|c|c|c|c|}
\hline $\begin{array}{l}\text { Prostate cancer } \\
\text { cell lines }\end{array}$ & Source of cell & $\begin{array}{l}\text { Type of bone } \\
\text { metastasis }\end{array}$ & $\begin{array}{l}\text { Androgen receptor } \\
\text { (AR)+ }\end{array}$ & $\begin{array}{l}\text { Prostate-specific } \\
\text { antigen (PSA)+ }\end{array}$ & Reference \\
\hline PC3 & Bone & Osteolytic & - & - & [107-110] \\
\hline LNCaP & $\begin{array}{l}\text { Supraclavicular } \\
\text { lymph node }\end{array}$ & Osteoblastic & + & + & {$[107,109,110]$} \\
\hline LNCaP-C4-2B & Subline of LNCaP & Osteoblastic & - & + & $\begin{array}{l}{[107,108} \\
111-115]\end{array}$ \\
\hline DU145 & Brain & Osteolytic & - & - & $\begin{array}{l}{[107,109} \\
116-118]\end{array}$ \\
\hline
\end{tabular}

Table 3. Translational models of prostate cancer bone metastasis.

\begin{tabular}{llll} 
Cell lines & Inoculation method & Number of cells used & Reference \\
\hline PC3 & Orthotopic & 200,000 or $1 \mathrm{~mm}^{3}$ of a subcutaneous tumour & {$[119,120]$} \\
\hline LNCaP & Orthotopic & $1,000,000$ & {$[121]$} \\
\hline LNCaP C4-2B & Subcutaneous & 200,000 & {$[120]$} \\
\hline LNCaP C4-2 & Orthotopic & $1,000,000$ & {$[111]$} \\
& Subcutaneous & $1,000,000$ & {$[111]$}
\end{tabular}

of tumor cells by considering to add autophagy inhibitors related to the AKT signal transduction pathway enabled further exploration of the treatment methods to inhibit bone metastasis. This design could provide a macroscopic direction for exploring the diagnosis and therapy of autophagy and bone metastasis from PC.

\section{DATA AVAILABILITY}

The datasets used and analyzed during the current study are available from the corresponding author on reasonable request.

\section{REFERENCES}

1. Global Burden of Disease Cancer Collaboration, Fitzmaurice C, Allen C, Barber RM, Barregard L, Bhutta ZA, et al. Global, regional, and national cancer incidence, mortality, years of life lost, years lived with disability, and disability-adjusted life-years for 32 cancer groups, 1990 to 2015: a systematic analysis for the Global Burden of Disease Study. JAMA Oncol. 2017;3:524-48.

2. Zhang $X$. Interactions between cancer cells and bone microenvironment promote bone metastasis in prostate cancer. Cancer Commun. 2019;39:76.

3. Sfanos KS, Yegnasubramanian S, Nelson WG, De, Marzo AM. The inflammatory microenvironment and microbiome in prostate cancer development. Nat Rev Urol. 2018;15:11-24. 
4. Huggins C, Hodges CV. Studies on prostatic cancer: I. The effect of castration, of estrogen and of androgen injection on serum phosphatases in metastatic carcinoma of the prostate. 1941. J Urol. 2002;168:9-12.

5. Wang G, Zhao D, Spring DJ, DePinho RA. Genetics and biology of prostate cancer. Genes Dev. 2018;32:1105-40.

6. Pernar CH, Ebot EM, Wilson KM, Mucci LA. The epidemiology of prostate cancer. Cold Spring Harb Perspect Med. 2018;8:a030361.

7. Siegel RL, Miller KD, Jemal A. Cancer statistics, 2019. CA Cancer J Clin. 2019;69:7-34.

8. Fizazi K, Tran N, Fein L, Matsubara N, Rodriguez-Antolin A, Alekseev BY, et al. Abiraterone plus prednisone in metastatic, castration-sensitive prostate cancer. N Engl J Med. 2017;377:352-60.

9. Berish RB, Ali AN, Telmer PG, Ronald JA, Leong HS. Translational models of prostate cancer bone metastasis. Nat Rev Urol. 2018;15:403-21.

10. Parzych KR, Klionsky DJ. An overview of autophagy: morphology, mechanism, and regulation. Antioxid Redox Signal. 2014;20:460-73.

11. Larabi $A$, Barnich $N$, Nguyen $H T T$. New insights into the interplay between autophagy, gut microbiota and inflammatory responses in IBD. Autophagy. 2020;16:38-51.

12. Kimmelman AC, White E. Autophagy and tumor metabolism. Cell Metab. 2017;25:1037-43.

13. Camuzard O, Santucci-Darmanin S, Carle GF, Pierrefite-Carle V. Autophagy in the crosstalk between tumor and microenvironment. Cancer Lett. 2020;490:143-53.

14. Xu Z, Han X, Ou D, Liu T, Li Z, Jiang G, et al. Targeting PI3K/AKT/mTOR-mediated autophagy for tumor therapy. Appl Microbiol Biotechnol. 2020;104:575-87.

15. Du C, Zhang T, Xiao X, Shi Y, Duan H, Ren Y. Protease-activated receptor-2 promotes kidney tubular epithelial inflammation by inhibiting autophagy via the PI3K/Akt/mTOR signalling pathway. Biochem J. 2017;474:2733-47.

16. Hussain M, Fizazi K, Saad F, Rathenborg P, Shore N, Ferreira U, et al. Enzalutamide in men with nonmetastatic, castration-resistant prostate cancer. $\mathrm{N}$ Engl J Med. 2018:378:2465-74.

17. Gandaglia G, Karakiewicz PI, Briganti A, Passoni NM, Schiffmann J, Trudeau V, et al. Impact of the site of metastases on survival in patients with metastatic prostate cancer. Eur Urol. 2015;68:325-34.

18. Zajaczkowska R, Kocot-Kepska M, Leppert W, Wordliczek J. Bone pain in cancer patients: mechanisms and current treatment. Int J Mol Sci. 2019;20:6047.

19. Fornetti J, Welm AL, Stewart SA. Understanding the bone in cancer metastasis. J Bone Min Res. 2018;33:2099-113.

20. Ren D, Yang Q, Dai $Y$, Guo W, Du H, Song L, et al. Oncogenic miR-210-3p promotes prostate cancer cell EMT and bone metastasis via NF-kappaB signaling pathway. Mol Cancer. 2017;16:117.

21. Liu X, Chen L, Fan Y, Hong Y, Yang X, Li Y, et al. IFITM3 promotes bone metastasis of prostate cancer cells by mediating activation of the TGF-beta signaling pathway. Cell Death Dis. 2019;10:517.

22. Genna A, Vanwynsberghe AM, Villard AV, Pottier C, Ancel J, Polette M, et al. EMTassociated heterogeneity in circulating tumor cells: sticky friends on the road to metastasis. Cancers. 2020;12:1632.

23. Wang W, Yang X, Dai J, Lu Y, Zhang J, Keller ET. Prostate cancer promotes a vicious cycle of bone metastasis progression through inducing osteocytes to secrete GDF15 that stimulates prostate cancer growth and invasion. Oncogene. 2019;38:4540-59.

24. Roodman GD. Mechanisms of bone metastasis. N Engl J Med. 2004;350:1655-64.

25. Yin JJ, Pollock CB, Kelly K. Mechanisms of cancer metastasis to the bone. Cell Res. 2005;15:57-62.

26. Labanca E, Vazquez ES, Corn PG, Roberts JM, Wang F, Logothetis $C J$, et al. Fibroblast growth factors signaling in bone metastasis. Endocr Relat Cancer. 2020;27:R255-R65.

27. Fuchs $\mathrm{C}$. [Health policy considerations on the AIDS problems and risks in surgery]. Langenbecks Arch Chir. 1988;Suppl 2:51-6.

28. Wu X, Li F, Dang L, Liang C, Lu A, Zhang G. RANKL/RANK system-based mechanism for breast cancer bone metastasis and related therapeutic strategies. Front Cell Dev Biol. 2020;8:76.

29. Fournier PG, Juarez P, Jiang G, Clines GA, Niewolna M, Kim HS, et al. The TGFbeta signaling regulator PMEPA1 suppresses prostate cancer metastases to bone. Cancer Cell. 2015;27:809-21.

30. Cai WL, Huang WD, Li B, Chen TR, Li ZX, Zhao CL, et al. microRNA-124 inhibits bone metastasis of breast cancer by repressing Interleukin-11. Mol Cancer. 2018;17:9.

31. Nguyen DP, Li J, Tewari AK. Inflammation and prostate cancer: the role of interleukin 6 (IL-6). BJU Int. 2014:113:986-92.

32. Dolloff NG, Shulby SS, Nelson AV, Stearns ME, Johannes GJ, Thomas JD, et al. Bone-metastatic potential of human prostate cancer cells correlates with Akt/ PKB activation by alpha platelet-derived growth factor receptor. Oncogene. 2005;24:6848-54.

33. Pradhan AK, Bhoopathi P, Talukdar S, Shen XN, Emdad L, Das SK, et al. Recombinant MDA-7/IL24 suppresses prostate cancer bone metastasis through downregulation of the Akt/Mcl-1 pathway. Mol Cancer Ther. 2018:17:1951-60.
34. Tang Y, Pan J, Huang S, Peng X, Zou X, Luo Y, et al. Downregulation of miR-133a$3 p$ promotes prostate cancer bone metastasis via activating PI3K/AKT signaling. J Exp Clin Cancer Res. 2018;37:160.

35. Tseng JC, Huang SH, Lin CY, Wang BJ, Huang SF, Shen YY, et al. ROR2 suppresses metastasis of prostate cancer via regulation of miR-199a-5p-PIAS3AKT2 signaling axis. Cell Death Dis. 2020;11:376.

36. Yan J, Ojo D, Kapoor A, Lin X, Pinthus JH, Aziz T, et al. Neural cell adhesion protein CNTN1 promotes the metastatic progression of prostate cancer. Cancer Res. 2016;76:1603-14.

37. Hansen AG, Arnold SA, Jiang M, Palmer TD, Ketova T, Merkel A, et al. ALCAM/ CD166 is a TGF-beta-responsive marker and functional regulator of prostate cancer metastasis to bone. Cancer Res. 2014;74:1404-15.

38. van den Hoogen $C$, van der Horst $G$, Cheung $H$, Buijs JT, Pelger RC, van der Pluijm $G$. The aldehyde dehydrogenase enzyme $7 A 1$ is functionally involved in prostate cancer bone metastasis. Clin Exp Metastasis. 2011:28:615-25.

39. Yu-Lee LY, Yu G, Lee YC, Lin SC, Pan J, Pan T, et al. Osteoblast-secreted factors mediate dormancy of metastatic prostate cancer in the bone via activation of the TGFbetaRIII-p38MAPK-pS249/T252RB pathway. Cancer Res. 2018;78:2911-24.

40. Wa $Q$, Huang S, Pan J, Tang $Y$, He S, Fu X, et al. miR-204-5p represses bone metastasis via inactivating NF-kappaB signaling in prostate cancer. Mol Ther Nucleic Acids. 2019;18:567-79.

41. Hashimoto K, Ochi H, Sunamura S, Kosaka N, Mabuchi Y, Fukuda T, et al. Cancersecreted hsa-miR-940 induces an osteoblastic phenotype in the bone metastatic microenvironment via targeting ARHGAP1 and FAM134A. Proc Natl Acad Sci USA. 2018:115:2204-9.

42. Jiang S, Mo C, Guo S, Zhuang J, Huang B, Mao X. Human bone marrow mesenchymal stem cells-derived microRNA-205-containing exosomes impede the progression of prostate cancer through suppression of RHPN2. J Exp Clin Cancer Res. 2019;38:495.

43. Miftakhova R, Hedblom A, Semenas J, Robinson B, Simoulis A, Malm J, et al. Cyclin A1 and P450 aromatase promote metastatic homing and growth of stemlike prostate cancer cells in the bone marrow. Cancer Res. 2016;76:2453-64.

44. Kim S, Huang W, Mottillo EP, Sohail A, Ham YA, Conley-Lacomb MK, et al. Posttranslational regulation of membrane type 1-matrix metalloproteinase (MT1-MMP) in mouse PTEN null prostate cancer cells: enhanced surface expression and differential O-glycosylation of MT1-MMP. Biochim Biophys Acta. 2010;1803:1287-97.

45. Anselmino N, Starbuck M, Labanca E, Cotignola J, Navone N, Gueron G, et al. Heme oxygenase- 1 is a pivotal modulator of bone turnover and remodeling: molecular implications for prostate cancer bone metastasis. Antioxid Redox Signal. 2020;32:1243-58.

46. Kimura T, Kuwata T, Ashimine S, Yamazaki M, Yamauchi C, Nagai K, et al. Targeting of bone-derived insulin-like growth factor-ll by a human neutralizing antibody suppresses the growth of prostate cancer cells in a human bone environment. Clin Cancer Res. 2010;16:121-9.

47. Beckham TH, Lu P, Cheng JC, Zhao D, Turner LS, Zhang X, et al. Acid ceramidasemediated production of sphingosine 1-phosphate promotes prostate cancer invasion through upregulation of cathepsin B. Int J Cancer. 2012;131:2034-43.

48. Rubenstein CS, Gard JMC, Wang M, McGrath JE, Ingabire N, Hinton JP, et al. Gene editing of alpha6 integrin inhibits muscle invasive networks and increases cell-cell biophysical properties in prostate cancer. Cancer Res. 2019;79:4703-14.

49. Wang Q, Xia N, Li T, Xu Y, Zou Y, Zuo Y, et al. SUMO-specific protease 1 promotes prostate cancer progression and metastasis. Oncogene. 2013;32:2493-8.

50. Kobayashi A, Okuda $H$, Xing F, Pandey PR, Watabe M, Hirota $S$, et al. Bone morphogenetic protein 7 in dormancy and metastasis of prostate cancer stemlike cells in bone. J Exp Med. 2011:208:2641-55.

51. Yuen HF, Chan YP, Cheung WL, Wong YC, Wang X, Chan KW. The prognostic significance of BMP-6 signaling in prostate cancer. Mod Pathol. 2008;21:1436-43.

52. Nandana S, Tripathi M, Duan P, Chu CY, Mishra R, Liu C, et al. Bone metastasis of prostate cancer can be therapeutically targeted at the TBX2-WNT signaling axis. Cancer Res. 2017:77:1331-44.

53. Li Y, Kucuk O, Hussain M, Abrams J, Cher ML, Sarkar FH. Antitumor and antimetastatic activities of docetaxel are enhanced by genistein through regulation of osteoprotegerin/receptor activator of nuclear factor-kappaB (RANK)/RANK ligand/MMP-9 signaling in prostate cancer. Cancer Res. 2006;66:4816-25.

54. Chen WY, Tsai YC, Yeh HL, Suau F, Jiang KC, Shao AN, et al. Loss of SPDEF and gain of TGFBI activity after androgen deprivation therapy promote EMT and bone metastasis of prostate cancer. Sci Signal. 2017;10:eaam6826.

55. Lee C, Whang YM, Campbell P, Mulcrone PL, Elefteriou F, Cho SW, et al. Dual targeting c-met and VEGFR2 in osteoblasts suppresses growth and osteolysis of prostate cancer bone metastasis. Cancer Lett. 2018;414:205-13.

56. Huang $Y$, Jin C, Hamana T, Liu J, Wang C, An L, et al. Overexpression of FGF9 in prostate epithelial cells augments reactive stroma formation and promotes prostate cancer progression. Int J Biol Sci. 2015;11:948-60. 
57. Chen N, Ye XC, Chu K, Navone NM, Sage EH, Yu-Lee LY, et al. A secreted isoform of ErbB3 promotes osteonectin expression in bone and enhances the invasiveness of prostate cancer cells. Cancer Res. 2007;67:6544-8.

58. Narla G, DiFeo A, Fernandez Y, Dhanasekaran S, Huang F, Sangodkar J, et al. KLF6-SV1 overexpression accelerates human and mouse prostate cancer progression and metastasis. J Clin Invest. 2008;118:2711-21.

59. Roca H, Jones JD, Purica MC, Weidner S, Koh AJ, Kuo R, et al. Apoptosis-induced CXCL5 accelerates inflammation and growth of prostate tumor metastases in bone. J Clin Investig. 2018;128:248-66.

60. Ganguly SS, Hostetter G, Tang L, Frank SB, Saboda K, Mehra R, et al. Notch3 promotes prostate cancer-induced bone lesion development via MMP-3. Oncogene. 2020;39:204-18.

61. Sawant Dessai A, Dominguez MP, Chen UI, Hasper J, Prechtl C, $\mathrm{Yu}$ C, et al. Transcriptional repression of SIRT3 potentiates mitochondrial aconitase activation to drive aggressive prostate cancer to the bone. Cancer Res. 2021;81:50-63.

62. Wen $S$, Wei $Y$, Zen $C$, Xiong $W$, Niu $Y$, Zhao $Y$. Long non-coding RNA NEAT1 promotes bone metastasis of prostate cancer through N6-methyladenosine. Mol Cancer. 2020;19:171.

63. Ge C, Zhao G, Li Y, Li H, Zhao X, Pannone G, et al. Role of Runx2 phosphorylation in prostate cancer and association with metastatic disease. Oncogene. 2016;35:366-76.

64. Kim B, Kim H, Jung S, Moon A, Noh DY, Lee ZH, et al. A CTGF-RUNX2-RANKL axis in breast and prostate cancer cells promotes tumor progression in bone. J Bone Min Res. 2020;35:155-66.

65. Matscheko N, Mayrhofer P, Wollert T. Passing membranes to autophagy: unconventional membrane tethering by Atg17. Autophagy. 2017;13:629-30.

66. Chen N, Tang X, Ye Z, Wang S, Xiao X. Methylmercury disrupts autophagic flux by inhibiting autophagosome-lysosome fusion in mouse germ cells. Ecotoxicol Environ Saf. 2020;198:110667.

67. Sahu R, Kaushik S, Clement CC, Cannizzo ES, Scharf B, Follenzi A, et al. Microautophagy of cytosolic proteins by late endosomes. Dev Cell. 2011;20:131-9.

68. Dikic I, Elazar Z. Mechanism and medical implications of mammalian autophagy. Nat Rev Mol Cell Biol. 2018;19:349-64.

69. Bagherniya M, Butler AE, Barreto GE, Sahebkar A. The effect of fasting or calorie restriction on autophagy induction: a review of the literature. Ageing Res Rev. 2018;47:183-97.

70. Levy JMM, Towers CG, Thorburn A. Targeting autophagy in cancer. Nat Rev Cancer. 2017;17:528-42.

71. Su Z, Yang Z, Xu Y, Chen Y, Yu Q. Apoptosis, autophagy, necroptosis, and cancer metastasis. Mol Cancer. 2015;14:48

72. Han T, Guo M, Gan M, Yu B, Tian X, Wang JB. TRIM59 regulates autophagy through modulating both the transcription and the ubiquitination of BECN1. Autophagy. 2018;14:2035-48.

73. Fimia GM, Stoykova A, Romagnoli A, Giunta L, Di Bartolomeo S, Nardacci R, et al. Ambra1 regulates autophagy and development of the nervous system. Nature. 2007;447:1121-5.

74. Costa AM, Fairley CK, Garland SM, Tabrizi SN. Evaluation of self-collected urine dip swab method for detection of Chlamydia trachomatis. Sex Health. 2009;6:213-6.

75. Sanchez-Garrido J, Shenoy AR. Regulation and repurposing of nutrient sensing and autophagy in innate immunity. Autophagy. 2021;17:1571-91.

76. Simicek M, Lievens S, Laga M, Guzenko D, Aushev VN, Kalev P, et al. The deubiquitylase USP33 discriminates between RALB functions in autophagy and innate immune response. Nat Cell Biol. 2013;15:1220-30.

77. Park JM, Seo M, Jung CH, Grunwald D, Stone M, Otto NM, et al. ULK1 phosphorylates Ser30 of BECN1 in association with ATG14 to stimulate autophagy induction. Autophagy. 2018;14:584-97.

78. Tong $X, G u$ J, Song R, Wang D, Sun Z, Sui C, et al. Osteoprotegerin inhibit osteoclast differentiation and bone resorption by enhancing autophagy via AMPK/ mTOR/p70S6K signaling pathway in vitro. J Cell Biochem. 2019;120:1630-42.

79. Sun X, Wang D, Zhang T, Lu X, Duan F, Ju L, et al. Eugenol attenuates cerebral ischemia-reperfusion injury by enhancing autophagy via AMPK-mTOR-P70S6K pathway. Front Pharmacol. 2020;11:84.

80. Zhou J, Jiang YY, Chen H, Wu YC, Zhang L. Tanshinone I attenuates the malignant biological properties of ovarian cancer by inducing apoptosis and autophagy via the inactivation of PI3K/AKT/mTOR pathway. Cell Prolif. 2020;53:e12739.

81. Kim YC, Guan KL. mTOR: a pharmacologic target for autophagy regulation. J Clin Investig. 2015;125:25-32.

82. Zhao GS, Gao ZR, Zhang Q, Tang XF, Lv YF, Zhang ZS, et al. TSSC3 promotes autophagy via inactivating the Src-mediated PI3K/Akt/mTOR pathway to suppress tumorigenesis and metastasis in osteosarcoma, and predicts a favorable prognosis. J Exp Clin Cancer Res. 2018;37:188

83. Liu W, Jiang D, Gong F, Huang $Y$, Luo $Y$, Rong $Y$, et al. miR-210-5p promotes epithelial-mesenchymal transition by inhibiting PIK3R5 thereby activating oncogenic autophagy in osteosarcoma cells. Cell Death Dis. 2020;11:93.
84. Dan Dunn J, Alvarez LA, Zhang X, Soldati T. Reactive oxygen species and mitochondria: a nexus of cellular homeostasis. Redox Biol. 2015;6:472-85.

85. Kaarniranta K, Uusitalo H, Blasiak J, Felszeghy S, Kannan R, Kauppinen A, et al. Mechanisms of mitochondrial dysfunction and their impact on age-related macular degeneration. Prog Retin Eye Res. 2020;79:100858.

86. Gong Y, Fan Z, Luo G, Yang C, Huang Q, Fan K, et al. The role of necroptosis in cancer biology and therapy. Mol Cancer. 2019;18:100.

87. Utz JA, Kransdorf MJ, Jelinek JS, Moser RP Jr., Berrey BH. MR appearance of fibrous dysplasia. J Comput Assist Tomogr. 1989;13:845-51.

88. Song X, Zhu S, Xie Y, Liu J, Sun L, Zeng D, et al. JTC801 induces pH-dependent death specifically in cancer cells and slows growth of tumors in mice. Gastroenterology. 2018;154:1480-93.

89. Liu H, He Z, Simon HU. Targeting autophagy as a potential therapeutic approach for melanoma therapy. Semin Cancer Biol. 2013;23:352-60.

90. Endo S, Nakata K, Ohuchida K, Takesue S, Nakayama H, Abe T, et al. Autophagy is required for activation of pancreatic stellate cells, associated with pancreatic cancer progression and promotes growth of pancreatic tumors in mice. Gastroenterology. 2017;152:1492.e24-506.e24.

91. Orienti I, Francescangeli F, De Angelis ML, Fecchi K, Bongiorno-Borbone L, Signore $M$, et al. A new bioavailable fenretinide formulation with antiproliferative, antimetabolic, and cytotoxic effects on solid tumors. Cell Death Dis. 2019;10:529.

92. Ouyang DY, Xu LH, He XH, Zhang YT, Zeng LH, Cai JY, et al. Autophagy is differentially induced in prostate cancer LNCaP, DU145 and PC-3 cells via distinct splicing profiles of ATG5. Autophagy. 2013;9:20-32.

93. He Z, Guo L, Shu Y, Fang Q, Zhou H, Liu Y, et al. Autophagy protects auditory hair cells against neomycin-induced damage. Autophagy. 2017;13: 1884-904.

94. Kim KY, Park Kl, Kim SH, Yu SN, Park SG, Kim YW, et al. Inhibition of autophagy promotes salinomycin-induced apoptosis via reactive oxygen species-mediated $\mathrm{PI} 3 \mathrm{~K} / \mathrm{AKT} / \mathrm{mTOR}$ and ERK/p38 MAPK-dependent signaling in human prostate cancer cells. Int J Mol Sci. 2017;18:1088.

95. Zhao Y, Feng X, Li B, Sha J, Wang C, Yang T, et al. Dexmedetomidine protects against lipopolysaccharide-induced acute kidney injury by enhancing autophagy through inhibition of the PI3K/AKT/mTOR pathway. Front Pharmacol. 2020;11:128.

96. Tsvetkov AS, Miller J, Arrasate M, Wong JS, Pleiss MA, Finkbeiner S. A small-molecule scaffold induces autophagy in primary neurons and protects against toxicity in a Huntington disease model. Proc Natl Acad Sci USA. 2010;107:16982-7.

97. Rosich L, Xargay-Torrent S, Lopez-Guerra M, Campo E, Colomer D, Roue G. Counteracting autophagy overcomes resistance to everolimus in mantle cell lymphoma. Clin Cancer Res. 2012;18:5278-89.

98. Sinha S, Roy S, Reddy BS, Pal K, Sudhakar G, lyer S, et al. A lipid-modified estrogen derivative that treats breast cancer independent of estrogen receptor expression through simultaneous induction of autophagy and apoptosis. Mol Cancer Res. 2011;9:364-74.

99. Haas NB, Appleman LJ, Stein M, Redlinger M, Wilks M, Xu X, et al. Autophagy inhibition to augment mTOR inhibition: a phase $1 / I$ trial of everolimus and hydroxychloroquine in patients with previously treated renal cell carcinoma. Clin Cancer Res. 2019;25:2080-7.

100. Vogel KR, Ainslie GR, Gibson KM. mTOR inhibitors rescue premature lethality and attenuate dysregulation of GABAergic/glutamatergic transcription in murine succinate semialdehyde dehydrogenase deficiency (SSADHD), a disorder of GABA metabolism. J Inherit Metab Dis. 2016;39:877-86.

101. Cordaro M, Paterniti I, Siracusa R, Impellizzeri D, Esposito E, Cuzzocrea S. KU0063794, a dual mTORC1 and mTORC2 inhibitor, reduces neural tissue damage and locomotor impairment after spinal cord injury in mice. Mol Neurobiol. 2017;54:2415-27.

102. Kocaturk NM, Akkoc Y, Kig C, Bayraktar O, Gozuacik D, Kutlu O. Autophagy as a molecular target for cancer treatment. Eur J Pharm Sci. 2019;134:116-37.

103. Mitchell R, Hopcroft LEM, Baquero P, Allan EK, Hewit K, James D, et al. Targeting $B C R-A B L-i n d e p e n d e n t ~ T K I$ resistance in chronic myeloid leukemia by $\mathrm{mTOR}$ and autophagy inhibition. J Natl Cancer Inst. 2018;110:467-78.

104. Cerniglia GJ, Karar J, Tyagi S, Christofidou-Solomidou M, Rengan R, Koumenis C, et al. Inhibition of autophagy as a strategy to augment radiosensitization by the dual phosphatidylinositol 3-kinase/mammalian target of rapamycin inhibitor NVP-BEZ235. Mol Pharm. 2012;82:1230-40.

105. Musiwaro $P$, Smith $M$, Manifava $M$, Walker SA, Ktistakis NT. Characteristics and requirements of basal autophagy in HEK 293 cells. Autophagy. 2013;9:1407-17.

106. Wang Z, Zhou H, Zheng H, Zhou X, Shen G, Teng X, et al. Autophagy-based unconventional secretion of HMGB1 by keratinocytes plays a pivotal role in psoriatic skin inflammation. Autophagy. 2021;17:529-52.

107. Sobel RE, Sadar MD. Cell lines used in prostate cancer research: a compendium of old and new lines-part 1.J Urol. 2005;173:342-59. 
108. Shi XB, Nesslinger NJ, Deitch AD, Gumerlock PH, deVere White RW. Complex functions of mutant p53 alleles from human prostate cancer. Prostate. 2002;51:59-72.

109. Vlietstra RJ, van Alewijk DC, Hermans KG, van Steenbrugge GJ, Trapman J. Frequent inactivation of PTEN in prostate cancer cell lines and xenografts. Cancer Res. 1998;58:2720-3.

110. Carroll AG, Voeller HJ, Sugars L, Gelmann EP. p53 oncogene mutations in three human prostate cancer cell lines. Prostate. 1993;23:123-34.

111. Thalmann GN, Anezinis PE, Chang SM, Zhau HE, Kim EE, Hopwood VL, et al. Androgen-independent cancer progression and bone metastasis in the LNCaP model of human prostate cancer. Cancer Res. 1994;54:2577-81.

112. Conley-LaComb MK, Saliganan A, Kandagatla P, Chen YQ, Cher ML, Chinni SR. PTEN loss mediated Akt activation promotes prostate tumor growth and metastasis via CXCL12/CXCR4 signaling. Mol Cancer. 2013;12:85.

113. Wu TT, Sikes RA, Cui Q, Thalmann GN, Kao C, Murphy CF, et al. Establishing human prostate cancer cell xenografts in bone: induction of osteoblastic reaction by prostate-specific antigen-producing tumors in athymic and SCID/bg mice using LNCaP and lineage-derived metastatic sublines. Int J Cancer. 1998;77:887-94.

114. Jia L, Coetzee GA. Androgen receptor-dependent PSA expression in androgenindependent prostate cancer cells does not involve androgen receptor occupancy of the PSA locus. Cancer Res. 2005;65:8003-8.

115. Gravina GL, Mancini A, Sanita P, Vitale F, Marampon F, Ventura L, et al. KPT-330, a potent and selective exportin-1 (XPO-1) inhibitor, shows antitumor effects modulating the expression of cyclin D1 and survivin [corrected] in prostate cancer models. BMC Cancer. 2015;15:941.

116. Stone KR, Mickey DD, Wunderli H, Mickey GH, Paulson DF. Isolation of a human prostate carcinoma cell line (DU 145). Int J Cancer. 1978;21:274-81.

117. Bajgelman MC, Strauss BE. The DU145 human prostate carcinoma cell line harbors a temperature-sensitive allele of p53. Prostate. 2006;66:1455-62.

118. Lamoureux F, Ory B, Battaglia S, Pilet P, Heymann MF, Gouin F, et al. Relevance of a new rat model of osteoblastic metastases from prostate carcinoma for preclinical studies using zoledronic acid. Int J Cancer. 2008;122:751-60.

119. Yang $M$, Jiang $P$, Sun FX, Hasegawa S, Baranov E, Chishima T, et al. A fluorescent orthotopic bone metastasis model of human prostate cancer. Cancer Res. 1999;59:781-6.

120. Havens AM, Pedersen EA, Shiozawa $Y$, Ying $C$, Jung $Y$, Sun $Y$, et al. An in vivo mouse model for human prostate cancer metastasis. Neoplasia. 2008;10:371-80.

121. Jantscheff P, Ziroli V, Esser N, Graeser R, Kluth J, Sukolinskaya A, et al. Anti-metastatic effects of liposomal gemcitabine in a human orthotopic LNCaP prostate cancer xenograft model. Clin Exp Metastasis. 2009;26:981-92.

\section{AUTHOR CONTRIBUTIONS}

Conceptualization, material preparation, writing-original draft preparation: YW; writing, editing, and review: YW, NW, and NJ. All authors have read and approved the final manuscript.

\section{FUNDING}

This work was supported by National Natural Science Foundation of China [grant numbers 81872079 and 81572538], the Natural Science Foundation of Tianjin City [grant numbers 11JCZDJC19700, 16JCZDJC34400, 20140117, and 2010KZ95] and Tianjin Municipal Bureau of Public Health [grant numbers ZC20131].

\section{COMPETING INTERESTS}

The authors declare no competing interests.

\section{ADDITIONAL INFORMATION}

Correspondence and requests for materials should be addressed to Ning Jiang.

Reprints and permission information is available at http://www.nature.com/ reprints

Publisher's note Springer Nature remains neutral with regard to jurisdictional claims in published maps and institutional affiliations.

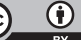

Open Access This article is licensed under a Creative Commons Attribution 4.0 International License, which permits use, sharing, adaptation, distribution and reproduction in any medium or format, as long as you give appropriate credit to the original author(s) and the source, provide a link to the Creative Commons license, and indicate if changes were made. The images or other third party material in this article are included in the article's Creative Commons license, unless indicated otherwise in a credit line to the material. If material is not included in the article's Creative Commons license and your intended use is not permitted by statutory regulation or exceeds the permitted use, you will need to obtain permission directly from the copyright holder. To view a copy of this license, visit http://creativecommons. org/licenses/by/4.0/.

(c) The Author(s) 2021, corrected publication 2021 